\title{
PENGARUH KECERDASAN EMOSI DAN BUDAYA RELIGIUS TERHADAP PERILAKU ETIS MAHASISWA PERGURUAN TINGGI KEMENTERIAN AGAMA SE-LOMBOK
}

\author{
Fathul Maujud1; Safroni Isrososiawan'; Muhammad Nurman ${ }^{3}$ \\ Universitas Islam Negeri Mataram, Indonesia \\ fathul@uinmataram.ac.id; safroni@uinmataram.ac.id; mnurman@uinmataram.ac.id
}

\begin{abstract}
ABSTRAK
Tujuan penelitian ini adalah untuk mengetahui: Pengaruh kecerdasan emosi dan budaya religius terhadap perilaku etis mahasiswa Perguruan Tinggi Kementerian Agama se-Lombok. Penelitian menggunakan pendekatan kuantitaif, karena data-data yang dikumpulkan adalah data berupa angka-angka. Metode penelitian yang digunakan adalah metode eks post fakto. Instrumen yang digunakan adalah angket jenis angket tertutup, yang pilihan jawabannya sudah disediakan sehingga mahasiswa tinggal memilih poin yang sesuai dengan karakter mereka. Data yang digunakan adalah data valid berdasarkan Uji Normalitas dan Uji Linieritas. Uji hipotesis menggunakan teknik analisis statistik regresi ganda. Kesimpulan yang diperoleh dari hasil penelitian ini adalah terdapat pengaruh kecerdasan emosi dan budaya religius terhadap perilaku etis mahasiswa Perguruan Tinggi Kementerian Agama seLombok, hal ini dibuktikan bahwa pada taraf signifikansi $\alpha 0,05$ diperoleh $F_{\text {hitung }}\left(F_{h}=287.76\right)$ lebih besar dari $F_{\text {tabel }}\left(F_{t} \alpha 0,05=\right.$ 3.063) sehingga $\mathrm{H}_{\mathrm{o}}$ ditolak dan $\mathrm{H}_{1}$ diterima.
\end{abstract}

Kata Kunci: Kecerdasan emosi, budaya religius, perilaku etis.

\begin{abstract}
The purpose of this study has a look at becoming to determine the effect of emotional intelligence and religious culture on the ethical behavior of college students in Higher Education on the Ministry of Religion Affairs in Lombok. The research method used is an ex post facto quantitative study. The instrument used was a closed questionnaire, college students only need to select points that suit their character. The data used is statistics that have been validated based on the Normality Test and Linearity Test. Hypothesis testing used multiple regression statistical analysis techniques. The conclusion received from the results of this study is that there may be an influence of emotional intelligence and religious culture at the ethical behavior of college students, this is proven that at a significant level of $\alpha 0.05$ received $\mathrm{F}_{\mathrm{h}}=287.76$ is greater than $\mathrm{F}_{\mathrm{t}} \alpha 0.05=3.063$ in order that $\mathrm{H}_{\mathrm{o}}$ is rejected and $\mathrm{H}_{1}$ is accepted.
\end{abstract}

Keywords: Emotional intelligence, religious culture, ethical behavior. 


\section{PENDAHULUAN}

Perguruan tinggi merupakan penghasil sumber daya manusia yang diharapkan dapat memenuhi tenaga profesional yang memiliki kualifikasi keahlian sesuai bidang ilmunya dan juga memiliki perilaku etis yang tinggi. Perguruan tinggi sebagai lembaga formal berfungsi untuk menyiapkan caloncalon sarjana yang professional, bertanggungjawab menyiapkan para mahasiswanya tidak saja dari sisi kemampuan teknis dan analitis tetapi juga mempersiapkan kemampuan menghadapi masalah etika yang akan mereka hadapi di dunia kerja. Proses ketika menjadi mahasiswa sangat berpengaruh besar. Apabila selama di perguruan tinggi mereka sudah berperilaku etis maka kemungkinan besar perilaku etis tersebut akan terbawa sampai nanti mereka menjadi professional di dunia kerja dan begitu pula sebaliknya.

Berdasarkan hasil observasi terhadap beberapa perilaku mahasiswa yang tidak etis, seperti tidak mematuhi aturan yang berlaku, semangat pengabdian yang rendah, tidak mengerjakan tugas, kurang memiliki integritas, kurangnya kerjasama, tidak bersikap objektif, menyontek, membuat gaduh saat ujian (mengobrol dengan teman), adanya mahasiswa yang melakukan pemalsuan presensi perkuliahan, tidak ikut berkontribusi dalam mengerjakan tugas kelompok, sering terlambat dalam menghadiri perkuliahan, pada saat perkulihan berlangsung banyak mahasiswa yang tidak memperhatikan dosen ketika menerangkan materi dan banyak lagi tindakan tidak etis yang dilakukan ooleh mahasiswa.

Perguruan tinggi terlebih perguruan tinggi keagamaan perlu memahami faktor-faktor apa saja yang dapat mempengaruhi perilaku etis pada mahasiswa. Kecerdasan emosional adalah kemampuan untuk mengenali perasaan sendiri maupun orang lain, untuk memotivasi diri sendiri, dan untuk mengendalikan emosi dengan baik, baik dalam diri sendiri maupun dengan orang lain. Dengan kemampuan mengenali dan mengelola emosi diri, maka individu dapat bertindak secara etis sesuai dengan norma dan nilai yang berlaku serta dengan tujuan menjaga hubungan dengan masyarakat. 
Faktor lain yang mempengaruhi perilaku etis mahasiswa adalah religiusitas. Religiusitas merupakan suatu sistem yang terintegrasi dari keyakinan (belief), gaya hidup, aktivitas ritual dan institusi yang memberikan makna dalam kehidupan manusia dan mengarahkan manusia pada nilai-nilai suci.

Berdasarkan uraian-uraian dalam latar belakang permasalahan maka permasalahan yang dapat dirumuskan: Apakah ada pengaruh kecerdasan emosi dan budaya religius terhadap perilaku etis mahasiswa Perguruan Tinggi Kementerian Agama se-Lombok?

\section{LANDASAN TEORI}

\section{Perilaku Etis}

Etika dalam bahasa latin "ethica," berarti falsafah moral. Ia merupakan pedoman cara bertingkah laku yang baik dari sudut pandang budaya, susila serta agama (Martandi, Farid, \& Suranta, 2006). Istilah etika jika dilihat dalam Kamus Besar Bahasa Indonesia (1998), memiliki tiga arti, yang salah satunya adalah nilai mengenai benar dan salah yang dianut suatu golongan atau masyarakat.

Secara etimologis kata etika berasal dari bahasa Yunani yaituethos dan ethikos, ethos yang berarti sifat, watak, adat, kebiasaan, tempatyang baik. Ethikos berarti susila, keadaban, atau kelakuan dan perbuatanyang baik. Kata "etika" dibedakan dengan kata "etik" dan "etiket". Kataetik berarti kumpulan asas atau nilai yang berkenaan dengan akhlak atau nilai mengenai benar dan salah yang dianut suatu golongan ataumasyarakat. Adapun kata etiket berarti tata cara atau adat, sopan santun danlain sebagainya dalam masyarakat beradaban dalam memelihara hubungan baik sesama manusia. Sedangkan secara terminologis etika berarti pengetahuan yangmembahas baik-buruk atau benar-tidaknya tingkah laku dan tindakan manusia serta sekaligus menyoroti kewajiban-kewajiban manusia.

Menurut Zubair (1987, hlm. 23), etika dan moral lebih kurang sama 
pengertiannya, tetapi dalam kegiatan sehari-hari terdapat perbedaan, yaitu moral untuk penilaian perbuatan yang dilakukan lebih banyak bersifat praktis, sedangkan etika adalah untuk pengkajian sistem nilai-nilai yang berlaku yang lebih banyak bersifat teori. Etika secara luas dapat diartikan sebagai serangkaian prinsip nilai atau moral. Menurut Griffin \& Ebert (2006, hlm. 58), perilaku etis adalah perilaku yang sesuai dengan norma-norma sosial yang diterima secara umum sehubungan dengan tindakan-tindakan yang benar dan baik. Perilaku etis ini dapat menentukan kualitas individu yang dipengaruhi oleh faktor-faktor yang diperoleh dari luar yang kemudian menjadi prinsip yang dijalani dalam bentuk perilaku.

Perilaku etis merupakan perilaku yang sesuai dengan norma-norma sosial yang diterima secara umum, berhubungan dengan tindakantindakan yang bermanfaat dan tidak membahayakan. Perilaku kepribadian merupakan karakteristik individu dalam menyesuaikan diri dengan lingkungan. Karakteristik tersebut meliputi sifat, kemampuan, nilai, keterampilan, sikap, dan intelegensi yang muncul dalam pola perilaku seseorang. Dapat disimpulkan bahwa perilaku merupakan perwujudan atau manifestasi karakteristik-karakteristik seseorang dalam menyesuaikan diri dengan lingkungan (Maryani \& Ludigdo, 2001, hlm. 4962).

\section{Budaya Religius}

Istilah "budaya" mula-mula datang dari dispilin ilmu Antropoogi Sosial. Apa yang tercakup dalam definisi budaya sangatlah luas arti dan maknanya. Istilah budaya dapat diartikan sebagai totalitas pola prilaku, kesenian, kepercayaan, kelembagaan, dan semua produk lain dari karya dan pemikiran manusia yang mencirikan kondisi suatu masyarakat atau penduduk yang ditransmisikan secara bersama (Kotter \& Heskett, 1992, hlm. 4). Budaya atau kebudayaan berasal dari bahasa Sanskerta yaitu buddhayah, yang merupakan bentuk jamak dari buddhi (budi atau akal) 
diartikan sebagai hal-hal yang berkaitan dengan budi dan akal manusia. Dalam bahasa Inggris, kebudayaan disebut culture, yang berasal dari kata Latin Colere, yaitu mengolah atau mengerjakan. Kata culture juga diterjemahkan dalam bahasa Indonesia Sebagai "kultur" atau kebudayaan.

Budaya merupakan salah satu disiplin ilmu Antropologi Sosial. Secara bahasa, budaya berasal dari bahasa Sansekerta yaitu buddayah, bentuk jamak dari buddhi yang berarti budi atau akal (Koentjadiningrat, hlm. 1974). Dalam Kamus Besar Bahasa Indonesia (1998, hlm. 149), budaya diartikan sebagai pikiran, adat istiadat, sesuatu yang sudah berkembang, dan menjadi kebiasaan yang sukar untuk dirubah. Maka dengan ini istilah budaya dapat diartikan sebagai totalitas pola perilaku, kesenian, kepercayaan, kelembagaan, dan semua produk lain dari karya dan pemikiran manusia yang mencirikan kondisi suatu masyarakat atau pendudukan yang ditransmisikan bersama (Sahlan, 2012, hlm. 70).

Beberapa pakar mencoba mendefinisikan budaya. Menurut Linton yang memberikan defenisi kebudayaan yang berbeda dengan pengertian budaya dalam kehidupan sehari-hari: budaya adalah seluruh cara kehidupan dari masyarakat dan tidak hanya mengenai sebagian tata cara hidup saja yang dianggap lebih tinggi dan lebih diinginkan. Jadi, budaya menunjuk pada berbagai aspek kehidupan. Istilah ini meliputi cara-cara berlaku, kepercayaan-kepercayaan dan sikap-sikap, dan juga hasil dari kegiatan manusia yang khas untuk suatu masyarakat atau kelompok penduduk tertentu.

Koentjaraningrat dikutip oleh Herminanto \& Winarno (2011, hlm. 25) mengungkapkan kebudayaan merupakan seluruh gagasan dan karya manusia yang harus dibiaskan dengan belajar beserta budi pekerti. Tylor mengartikan budaya adalah suatu kesatuan yang unik dan bukan jumlah dari bagian-bagian suatu kemampuan kreasi manusia yang immaterial, berbentuk kemampuan psikologis seperti ilmu pengetahuan, tekhnologi, kepercayaan, seni dan sebagainya (Sahlan, 2012, hlm. 71). 
Dari berbagai definisi budaya diatas, maka dapat diambil kesimpulan budaya adalah suatu ide atau pikiran yang mengandung nilai, keyakinan, norma dan sikap yang telah berkembang dan menjadi kebiasaan yang sukar dirubah. Agar budaya dapat menjadi nilai-nilai yang tahan lama, maka dibutuhkan proses internalisasi budaya.

Internalisasi merupakan proses menanamkan dan menumbuh kembangkan suatu nilai atau budaya menjadi bagian diri orang yang bersangkutan. Penanaman dan penumbuh kembangkan nilai dilakukan melalui berbagai metode pendidikan dan pengajaran. Dalam pendidikan dibutuhkan pengarahan, indoktrinisasi, brain wishing dan lain sebagainya. Selanjutnya adalah proses pembentukan budaya meliputi kontak budaya, penggalian budaya, seleksi budaya, pemantapan budaya, sosialisasi budaya, pewarisan budaya yang terjadi dalam hubungannya dengan lingkungan secara terus menerus dan berkesinambungan (Sahlan, 2012, hlm. 72).

Dalam proses pembentukan karakter peserta didik, kondisi lingkungan dan budaya setempat memiliki peran besar dalam mempengaruhi pola pikir dan membentuk kepribadian setiap individu. Karenanya dalam proses implementasi pendidikan karakter dibutuhkan strategi untuk menciptakan budaya yang baik, budaya religius yang membantu mendekatkan peserta didik dengan Sang Pencipta, dengan sesama, lingkungan dan lain sebagainya. Dalam hal ini, maka menjadi penting untuk membahas apa yang dimaksud dengan religius.

Religius adalah suatu sikap dan perilaku yang patuh dalam menjalankan atau melaksanakan ajaran agama yang dianutnya, toleran terhadap pelaksanaan ibadah agama lainnya dan hidup rukun dengan pemeluk agama lain (Syafri, 2012, hlm. 11). Religi, berasal dari bahasa latin "religio", bahasa Inggris; "religion", bahasa Arab "al-diin" atau agama. Religiusitas yaitu kepercayaan kepada Tuhan Yang Maha Esa dengan ajaran kebaktian dan kewajiban-kewajiban yang bertalian dengan 
kepercayaan itu. Budaya religius merupakan cara berfikir dan cara bertindak warga sekolah yang didasarkan atas nilai-nilai religius (keberagamaan). Religius menurut islam adalah menjalankan ajaran agama secara menyeluruh (Muallip, 2014, hlm. 15). Dengan demikian, budaya religius sekolah adalah terwujudnya nilai-nilai ajaran agama sebagai tradisi dalam berperilaku dan budaya organisasi yang diikuti oleh seluruh warga sekolah. Dengan menjadikan agama sebagai tradisi dalam sekolah maka secara sadar maupun tidak ketika warga sekolah mengikuti tradisi yang telah tertanam tersebut sebenarnya warga sekolah sudah melakukan ajaran agama (Muhaimin, 2001, hlm. 294).

Sehingga dapat disimpulkan, budaya religius adalah sekumpulan nilainilai agama yang melandasi prilaku, tradisi, kebiasaan keseharian, dan simbol-simbol yang dipraktekan oleh mahasiswa. Sebab itu budaya tidak hanya berbentuk simbolik semata sebagaimana yang tercemin di atas, tetapi didalamnya penuh dengan nilai-nilai. Perwujudan budaya tidak hanya muncul begitu saja, tetapi melalui proses pembudayaan (Sahlan, 2009, hlm. 16). Oleh karena itu budaya religius merupakan budaya yang memungkinkan setiap anggota sekolah beribadah, kontak dengan tuhan dengan cara yang telah ditetapkan agama dengan suasana tenang, bersih, dan hikmat. Dengan demikian budaya religius berkaitan dengan sekumpulan tindakan yang diwujudkan dalam prilaku, tradisi, kebiasaan sehari-hari dan simbol-simbol yang dipraktekkan berdasar agama, dalam konteks kerja. Menurut Hendricks dan Ludeman dalam Ari Ginanjar (2003, hlm. 249), ada beberapa sikap religius yang tampak dalam siri seseorang dalam menjalankan tugasnya, yaitu sebagai berikut: kejujuran, bermanfaat bagi orang lain, rendah hati, bekerja eisien, visi kedepan, disiplin tinggi, keseimbangan.

\section{Kecerdasan Emosi}

Pemaknaan terhadap emosional seringkali salah, sebab emosi pada umumnya dimaknai sebagai rasa dan perasaan-perasaan negatif lainnya 
(Goleman, 2004, hlm. 7). Emosi apabila dikendalikan adalah suatu kekuatan yang siap digali untuk mendapatkan kualitas hidup yang lebih baik. Hal ini menyiratkan bahwa emosi bisa menjadi cerdas. Emosi yang cerdas inilah yang disebut dengan kecerdasan emosional.

Menurut Ginanjar (2003, hlm. 62), kecerdasan emosional adalah sebuah kemampuan untuk mendengarkan bisikan emosi dan menjadikannya sebagai sumber informasi maha penting untuk memahami diri sendiri dan orang lain demi mencapai sebuah tujuan. Sementara itu Goleman (1996, hlm. 36) mengatakan: Emotional Intelligence: Abities such as being able to motivate one self and persist in the face of frustration: to control impulse and delay gratification; to regulate one's mood and keep distress from swamping the ability to think; to empathize and to hope.

Steven J. Stein dan Howard E. Book, ia menjelaskan bahwa kecerdasan emosional adalah serangkaian kemampuan, kompetensi, dan kecakapan nonkognitif yang memengaruhi kemampuan seseorang untuk berhasil mengatasi Book menjelaskan pendapat Peter Salovey dan John Mater, pencipta istilah kecerdasan emosional, bahwa kecerdasan emosional adalah mengenali perasaan, meraih dan membangkitkan perasaan untuk membantu pikiran, memahami perasaan dan maknanya, dan mengendalikan perasan secara mendalam sehingga membantu perkembangan emosi dan intelektual (Uno, 2006, hlm. 68-69).

Berdasarkan definisi di atas, maka dapat disimpulkan bahwa kecerdasan emosional adalah kemampuan seseorang mengelola perasaan dan emosi, baik pada diri sendiri dan pada orang lain dalam berinteraksi, kemampuan memotivasi diri sendiri dan berempati dengan informasi yang diperoleh dari seluruh potensi psikologi yang dimiliki untuk membimbing pikiran dan tindakan sehingga mampu mengatasi tuntutan hidup. 


\section{METODE PENELITIAN}

\section{Pendekatan dan Jenis Penelitian}

Pendekatan penelitian kuantitaif, karena data-data yang dikumpulkan adalah data berupa angka-angka. Metode penelitian yang digunakan adalah metode eks post fakto, karena peneliti tidak memberikan perlakuan atau memanipulasi perubahan khusus terhadap subjek penelitian. Keterangan-keterangan yang dihimpun adalah keterangan yang berdasarkan kejadian atau pengalaman yang telah berlangsung baik itu menyangkut kecerdasan emosi, budaya religius dan perilaku etis.

\section{Populasi dan Sampel Penelitian}

Populasi penelitian ini adalah seluruh mahasiswa dari semua perguruan tinggi di bawah kementerian agama yang ada di Lombok. Sampel adalah bagian dari populasi yang memiliki suatu atau lebih ciri yang sama, sehingga dapat menggambarkan keadaan yang sebenarnya dari keseluruhan populasi. Sedangkan sampling adalah metode atau teknik atau cara dalam penentuan atau pengambilan sampel. Teknik penarikan sampel yang digunakan adalah menggunakan random sampling.

\section{Variabel Penelitian dan Definisi Operasional}

Variabel bebas dalam penelitian ini adalah : (a) kecerdasan emosi yaitu kemampuan mengenali perasaan diri sendiri dan perasaan orang lain, memotivasi diri sendiri, serta mengelola emosi dengan baik pada diri sendiri dan dalam hubungannya dengan orang lain, (b) budaya religius, yaitu sekumpulan nilai-nilai agama yang melandasi prilaku, tradisi, kebiasaan keseharian, dan simbol-simbol yang dipraktekan oleh mahasiswa. Variabel terikat penelitian ini adalah perilaku etis, yaitu perilaku yang sesuai dengan norma-norma sosial yang diterima secara umum yang berkaitan dengan tindakan-tindakan yang benar dan baik atau tindakan yang bermanfaat dan tidak membahayakan. 


\section{Instrumen Penelitian}

Instrumen penelitian adalah alat atau yang digunakan oleh peneliti dalam mengumpulkan data. Instrumen yang digunakan dalam penelitian ini adalah angket. Angket yang dipakai berupa angket tertutup, yang sudah disediakan jawabannya sehingga mahasiswa tinggal memilih poin yang sesuai dengan karakter mereka. Berdasarkan dari jawaban yang diberikan, angket ini merupakan angket langsung, yaitu responden menjawab tentang dirinya. Berdasarkan bentuknya, angket yang digunakan dengan rating-scale atau biasanya menggunakan bentuk skala likert. Skala Likert digunakan untuk mengukur sikap, pendapat, dan persepsi seseorang atau sekelompok orang tentang fenomena sosial. Untuk penelitian ini, skala yang digunakan dengan 4 kemungkinan jawaban, yaitu sangat sesuai, sesuai, tidak sesuai, dan sangat tidak sesuai. Adapun indikator masing-masing variabel penelitian ini adalah :

Tabel 1. Kisi-Kisi Instrumen Penelitian

\begin{tabular}{|c|c|c|}
\hline Variabel & Sub Variabel & Indikator \\
\hline \multirow[t]{5}{*}{$\begin{array}{l}\text { Kecerdasan } \\
\text { emosional }\end{array}$} & Pengenalan diri & $\begin{array}{l}\text { Kesadaran emosi } \\
\text { Penilaian diri secara teliti } \\
\text { Percaya diri }\end{array}$ \\
\hline & Motivasi & $\begin{array}{l}\text { Dorongan prestasi kerja } \\
\text { Komitmen } \\
\text { Instropeksi }\end{array}$ \\
\hline & Empati & $\begin{array}{l}\text { Memahami } \\
\text { Memberi nasihat }\end{array}$ \\
\hline & Pengendalian diri & $\begin{array}{l}\text { Kendali diri } \\
\text { Pemuasan kesenangan } \\
\text { Sabar }\end{array}$ \\
\hline & Keterampilan sosial & $\begin{array}{l}\text { Komunikasi } \\
\text { Kemampuan mengorganisasi }\end{array}$ \\
\hline \multirow[t]{4}{*}{ Budaya religius } & Religius & $\begin{array}{l}\text { Rajin beribadah } \\
\text { Berdo'a } \\
\text { Merasa dekat dengan tuhan }\end{array}$ \\
\hline & Eksistensi diri & $\begin{array}{l}\text { Memaknai hidup dengan baik } \\
\text { Berpendirian pada kebenaran } \\
\text { Bersyukur }\end{array}$ \\
\hline & Sifat positif & $\begin{array}{l}\text { Jujur } \\
\text { Amanah } \\
\text { Toleran } \\
\text { Kesesuaian antara kata dengan } \\
\text { perbuatan }\end{array}$ \\
\hline & Kepedulian sosial & $\begin{array}{l}\text { Dermawan dan mau berbagi } \\
\text { Berkontribusi terhadap }\end{array}$ \\
\hline
\end{tabular}




\begin{tabular}{lll}
\hline Variabel & \multicolumn{1}{c}{ Sub Variabel } & \multicolumn{1}{c}{ Indikator } \\
\hline \multirow{3}{*}{ Perilaku etis } & Perilaku sesuai dengan & kesejahteraan \\
& Terbuka & Mematuhi aturan yang berlaku \\
& & Sesuai dengan surat perintah tugas \\
& Memiliki semangat pengabdian \\
& yang tinggi \\
& Tidak menolak tugas \\
& Memiliki keahlian \\
& Mengembangkan analisis \\
& Mampu membuat keputusan \\
& Memiliki integritas yang tinggi \\
& Bersikap obyektif \\
Perilaku berintraksi & Tidak dapat diintimidasi \\
dengan sesama & Menggalang kerjasama yang sehat \\
mahasiswa & Mengendalikan diri \\
& Menekan sifat iri \\
& Saling membimbing \\
& Saling memotivasi \\
& Saling mengingatkan \\
& Saling menkomunikasikan \\
& informasi \\
&
\end{tabular}

Untuk mendapatkan alat ukur yang baik harus dilakukan uji validitas dan uji reliabilitas. Untuk menghitung validitas digunakan rumus pearson produck moment.

$$
r_{x y}=\frac{\mathrm{N} \sum \mathrm{XY}-\left(\sum \mathrm{X}\right)\left(\sum \mathrm{Y}\right)}{\sqrt{\left[\mathrm{N} \cdot \sum x^{2}\left(\sum x\right)^{2}\left[\mathrm{~N} \cdot \sum \mathrm{Y}^{2}-\left(\sum \mathrm{Y}\right)^{2}\right]\right.}}
$$

Untuk keputusan valid atau tidaknya butir-butir soal akan digunakan taraf signifikansi 0,05. Apabila nilai r-hitung dinyatakan lebih besar atau sama dengan $r$-kritis, maka butir tersebut dinyatakan valid, dan sebaliknya dinyatakan gugur.

Adapun rumus yang digunakan untuk menguji reliabilitas adalah rumus Alpha yaitu;

$$
r_{n}=\left(\frac{k}{k-1}\right)\left(1-\frac{\sum S_{t}}{S_{t}}\right)
$$

\section{Metode Pengumpulan Data}

Adapun metode pengumpulan data utama yang di gunakan dalam penelitian ini adalah metode angket dengan instrumen angket, sedangkan 
metode dokumentasi hanya sebagai metode tambahan atau pelengkap. Angket atau quesioner adalah alat untuk mengumpulkan data yang berupa daptar pertanyaan yang di sampaikan kepada responden untuk di jawab secara tertulis. Metode Dokumentasi adalah di tujukan untuk memperoleh data langsung dari tempat penelitian, meliputi buku-buku yang relevan, laporan kegiatan, foto-foto, film dokumenter, data yang relevan penelitian.

\section{Teknik Analisis Data}

Sebelum data digunakan atau dianalisis terlebih dahulu data tersebut diuji persyaratannya, uji persyarat yang digunakan adalah sebagai berikut : (a) Uji Normalitas dan (b) Uji Linieritas. Untuk menguji hipotesis dalam penelitian ini menggunakan teknik analisis statistik yaitu dengan rumus regresi ganda.

\section{HASIL PENELITIAN}

\section{Uji Validitas dan Reliabilitas Instrumen Penelitian}

Validitas adalah suatu ukuran yang menunjukkan tingkat-tingkat kevalidan atau kesahihan sesuatu instrumen. Sebuah instrumen dikatakan valid apabila dapat mengungkap data dari variabel yang diteliti secara tepat. Tinggi rendahnya validitas instrumen menunjukkan sejauhmana data yang terkumpul tidak menyimpang dari gambaran tentang validitas. Validitas instrumen dikelompokkan menjadi dua yaitu: validitas isi dan validitas butir. Validitas isi instrumen dapat dilihat pada penyusunan kisikisi yang dibuat, sedangkan validitas butir menggunakan rumus korelasi product moment, karena jenis data yang dianalisis adalah interval. Keputusan yang diambil dalam pengujian yaitu apabila nilai $\mathrm{r}_{\text {hitung }}$ lebih besar dibandingkan nilai $r_{\text {tabel, }}$ maka butir tersebut dikatakan valid. Sebaliknya apabila nilai $r_{\text {hitung }}$ lebih kecil dibandingkan nilai $r_{\text {tabel, maka }}$ butir tersebut dikatakan drop pada taraf signifikan 5\%.

Berdasarkan hasil penghitungan validitas butir diperoleh bahwa 30 butir soal dinyatakan valid dan 7 butir soal dinyatakan tidak valid untuk 
instrument kecerdasan emosi. Hasil penghitungan validitas butir instrument budaya religious diperoleh bahwa 35 butir soal dinyatakan valid dan 5 butir soal dinyatakan tidak valid dan hasil penghitungan validitas butir instrument perilaku etis diperoleh bahwa semua butir soal dinyatakan valid.

\section{Penyajian Data}

Skor tertinggi kecerdasn emosi mahasiswa adalah 109 dan skor paling rendah 67. Kelompok ini memiliki nilai rerata 90.41, modus 91.5, median 90.5, varians 120.47 dan simpangan baku 10.98. Distribusi frekuensi nilai kecerdasan emosi mahasiswa dapat digolongkan ke dalam lima kelas interval dengan masing-masing frekuensi absolut dan kumulatif, relatif persen dan relatif kumulatif :

Tabel 2. Distribusi Frekuensi Data Kecerdasan Emosi Mahasiswa

\begin{tabular}{ccccccc}
\hline No & $\begin{array}{c}\text { Kelas } \\
\text { Interval }\end{array}$ & $\begin{array}{c}\text { Nillai } \\
\text { Tengah }\end{array}$ & f absolut & f kum & f relatif \% & $\begin{array}{c}\text { Relatif } \\
\text { kum }\end{array}$ \\
\hline 1 & $67-72$ & 69,5 & 5 & 5 & 3.62 & 3.62 \\
2 & $73-78$ & 75,5 & 19 & 24 & 13.77 & 17.39 \\
3 & $79-84$ & 81,5 & 21 & 45 & 15.22 & 32.61 \\
4 & $85-90$ & 87,5 & 24 & 69 & 17.39 & 50.00 \\
5 & $91-96$ & 93,5 & 25 & 94 & 18.12 & 68.12 \\
6 & $97-102$ & 99,5 & 20 & 114 & 14.49 & 82.61 \\
7 & $103-108$ & 105,5 & 20 & 134 & 14.49 & 97.10 \\
8 & $109-114$ & 111,5 & 4 & 138 & 2.90 & 100.00 \\
-3 & Jumlah & 138 & & & \\
\hline
\end{tabular}

Nilai rerata kecerdasan emosi mahasiswa 90.41. Berdasarkan tabel 4.5, maka mahasiswa yang berada di bawah nilai rerata yaitu sejumlah 45 (32.61\%) orang dan jumlah mahasiswa yang memperoleh nilai di atas nilai rata-rata adalah 69 (50 \%) orang. Agar lebih jelas data kecerdasan emosi mahasiswa dalam bentuk hitogram, di bawah ini. 


\section{Gambar 4.1 Grafik Histogram Kecerdasan Emosi}

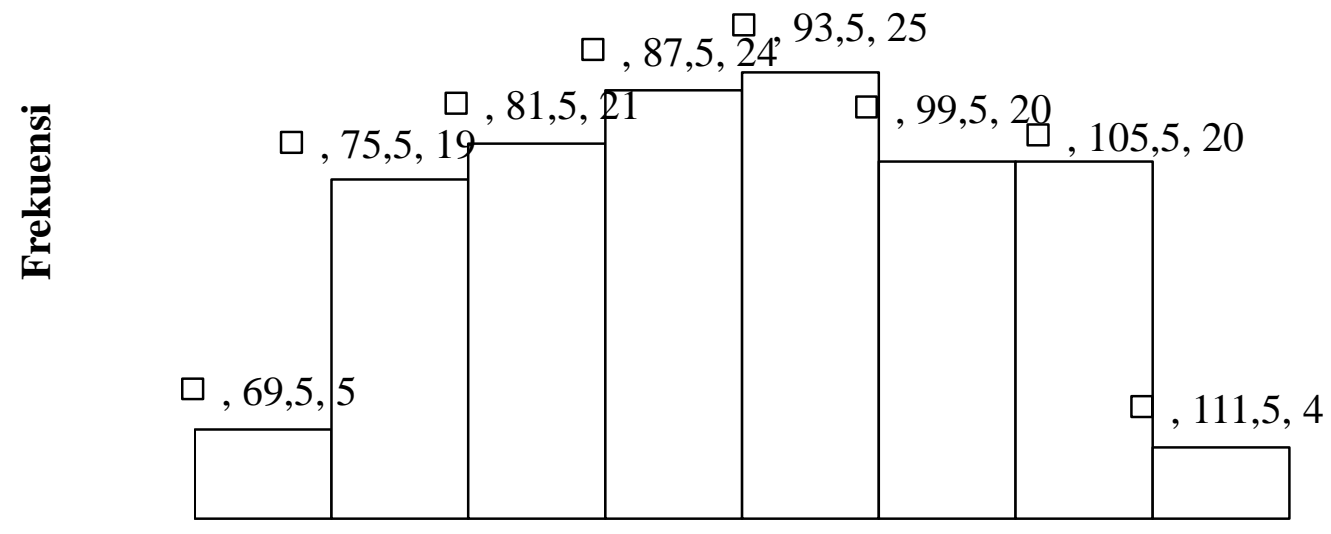

Titik Tengah

Setelah diukur budaya religius mahasiswa diperoleh skor terendah 59 dan skor tertinggi 106. Sedangkan nilai rata-rata 82.54, modus 81.41, median 82.5, varians 133.62, dan simpangan baku 11.56. Adapun distribusi frekuensi:

Table 3. Distribusi Frekuensi Data Budaya Religius

\begin{tabular}{ccccccc}
\hline No & $\begin{array}{c}\text { Kelas } \\
\text { Interval }\end{array}$ & $\begin{array}{c}\text { Nillai } \\
\text { Tengah }\end{array}$ & f absolut & f kum & $\begin{array}{c}\text { f relatif } \\
\%\end{array}$ & $\begin{array}{c}\text { Relatif } \\
\text { kum }\end{array}$ \\
\hline 1 & $59-64$ & 61,5 & 8 & 8 & 5.80 & 5.80 \\
2 & $65-70$ & 67,5 & 18 & 26 & 13.04 & 18.84 \\
3 & $71-76$ & 73,5 & 17 & 43 & 12.32 & 31.16 \\
4 & $77-82$ & 79,5 & 26 & 69 & 18.84 & 50.00 \\
5 & $83-88$ & 85,5 & 24 & 93 & 17.39 & 67.39 \\
6 & $89-94$ & 91,5 & 19 & 112 & 13.77 & 81.16 \\
7 & $95-100$ & 97,5 & 19 & 137 & 13.77 & 99.28 \\
8 & $101-106$ & 103,5 & 7 & 138 & 5.07 & 100.00 \\
\hline$-9---138$ & & & \\
\hline
\end{tabular}

Tabel 4.6 dapat dijelaskan bahwa jumlah mahasiswa yang memperoleh di atas skor rata-rata sebanyak 69 orang (50\%) dan 43 orang (31.16 \%) mendapat nilai di bawah skor rataa-rata. Sajian data tabel di atas dapat diperjelas dalam bentuk histogram: 


\section{Gambar 4.2 Grafik Histogram Budaya Religius}

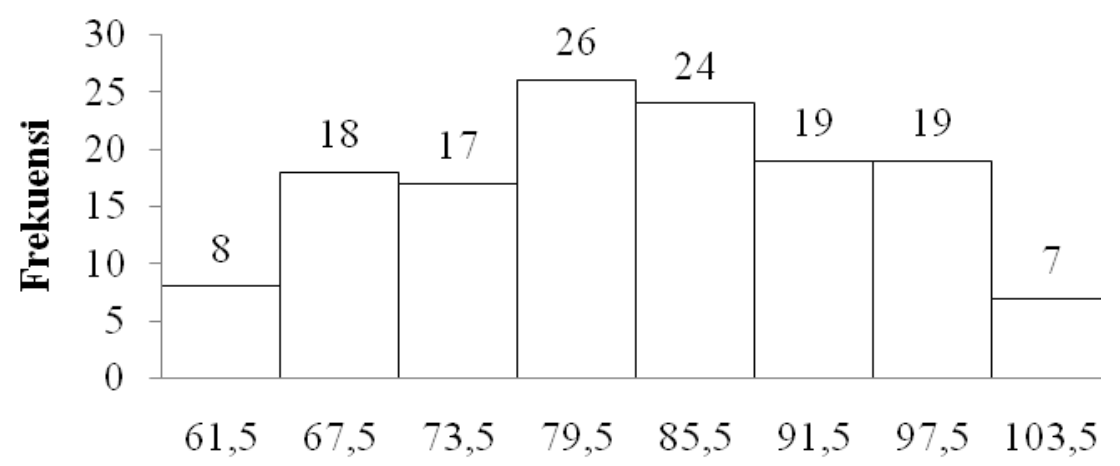

Titik Tengah

Setelah diukur perilaku etis mahasiswa diperoleh skor terendah 50 dan skor tertinggi 135 . Sedangkan nilai rata-rata 91.67, modus 100.83, median 93.04, varians 463.39, dan simpangan baku 21.53. Adapun distribusi frekuensi:.

Table 3. Distribusi Frekuensi Data Perilaku Etis

\begin{tabular}{|c|c|c|c|c|c|c|}
\hline No & $\begin{array}{c}\text { Kelas } \\
\text { Interval }\end{array}$ & $\begin{array}{c}\text { Nillai } \\
\text { Tengah }\end{array}$ & f absolut & f kum & $\begin{array}{c}\text { f relative } \\
\%\end{array}$ & $\begin{array}{c}\text { Relatif } \\
\text { Kum }\end{array}$ \\
\hline 1 & $50-60$ & 55 & 13 & 13 & 9.42 & 9.42 \\
\hline 2 & $61-71$ & 66 & 16 & 29 & 11.59 & 21.01 \\
\hline 3 & $72-82$ & 77 & 21 & 50 & 15.22 & 36.23 \\
\hline 4 & $83-93$ & 88 & 20 & 70 & 14.49 & 50.72 \\
\hline 5 & $94-104$ & 99 & 24 & 94 & 17.39 & 68.12 \\
\hline 6 & $105-115$ & 110 & 22 & 116 & 15.94 & 84.06 \\
\hline 7 & $116-126$ & 121 & 18 & 134 & 13.04 & 97.10 \\
\hline 8 & $127-137$ & 132 & 4 & 138 & 2.90 & 100.00 \\
\hline \multicolumn{2}{|c|}{ Jumlah } & & 138 & & & \\
\hline
\end{tabular}

Tabel 4.7 dapat dijelaskan bahwa jumlah mahasiswa yang memperoleh di atas skor rata-rata sebanyak 68 orang (49.28 \%) dan 50 orang (36.23 \%) mendapat nilai di bawah skor rataa-rata. Sajian data tabel di atas dapat diperjelas dalam bentuk histogram: 


\section{Gambar 4.3 Grafik Histogram Perilaku Etis}

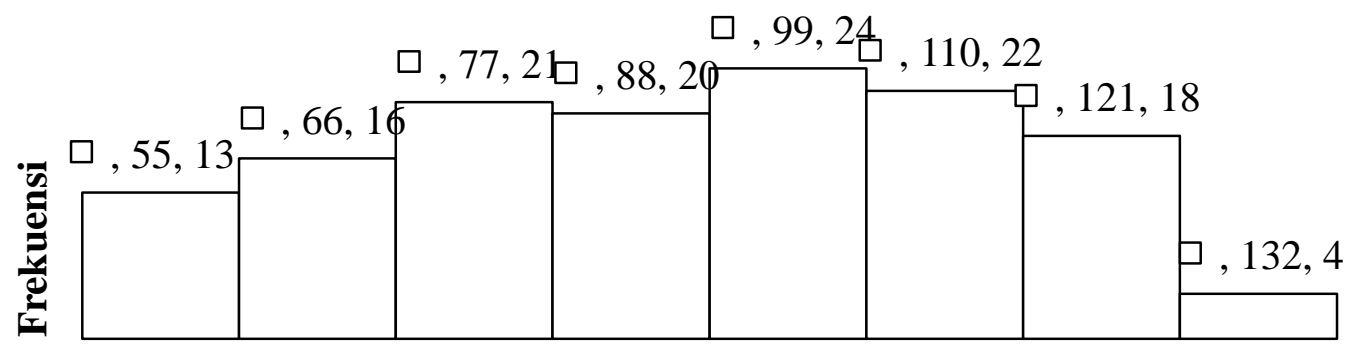

Titik Tengah

\section{Uji Persyaratan Analisis}

Tabel 4.8 Rangkuman Hasil Uji Normalitas

\begin{tabular}{|c|c|c|c|c|}
\hline Data Hasil Penelitian & $\mathrm{N}$ & $\chi^{2}{ }_{\text {hitung }}$ & $\chi^{2}$ tabel $\alpha 0,01$ dan 0.05 & Distribusi data \\
\hline $\mathrm{X}_{1}$ & 138 & 10,502 & 14,017 & Normal \\
\hline $\mathrm{X}_{2}$ & 138 & 8.601 & 14,017 & Normal \\
\hline $\mathrm{Y}$ & 138 & 11,425 & 14,017 & Normal \\
\hline
\end{tabular}

Kelompok data yang diuji linieritasnya, yaitu: kecerdasan emosi terhadap perilaku etis dan budaya religius terhadap perilaku etis. Berdasarkan hasil perhitungan uji linieritas diperoleh hasil sebagai berikut:

Tabel 4.9 Rangkuman Hasil Uji Linieritas Data

\begin{tabular}{|c|c|c|c|c|}
\hline $\begin{array}{c}\text { Kelompok } \\
\text { Data }\end{array}$ & db & $\mathbf{F}_{\text {hitung }}$ & $\begin{array}{l}F_{\text {tabel }} \\
0.05\end{array}$ & Keterangan \\
\hline $\mathrm{Y}, \mathrm{X}_{1}$ & $\begin{array}{c}\mathrm{db} \text { pembilang }=38 \text { dan } \\
\mathrm{db} \text { penyebut } 98\end{array}$ & 0.69 & 1,527 & Linier \\
\hline $\mathrm{Y}, \mathrm{X}_{2}$ & $\begin{array}{c}\mathrm{db} \text { pembilang }=38 \mathrm{dan} \\
\mathrm{db} \text { penyebut } 98\end{array}$ & 1,394 & 1,527 & Linier \\
\hline
\end{tabular}

\section{Hasil Uji Hipotesis}

Hasil pengujian hipotesis penelitian menggunakan regresi ganda diperoleh hasil : $F_{\text {hitung }}>F_{\text {tabel }}$ atau $287.76>3.063$, maka ada pengaruh kecerdasan emosi dan budaya religius terhadap perilaku etis mahasiswa Perguruan Tinggi Kementerian Agama se-Lombok. 


\section{PEMBAHASAN}

Hasil analisis data menggunakan menggunakan regresi ganda pada taraf signifikansi $\alpha$ 0,05 diperoleh $F_{\text {hitung }}\left(F_{h}=287.76\right)$ lebih besar dari $F_{\text {tabel }}\left(F_{t} \alpha\right.$ 0,05 = 3.063). Hal ini berarti Ho ditolak, untuk itu H1 diterima. Sehingga dapat disimpulkan bahwa terdapat pengaruh kecerdasan emosi dan budaya religius terhadap perilaku etis mahasiswa Perguruan Tinggi Kementerian Agama se-Lombok.

Mahasiswa merupakan subjek atau pelaku di dalam pergerakan pembaharuan atau subjek yang akan menjadi generasi-generasi penerus bangsa dan membangun bangsa dan tanah air ke arah yang lebih baik dituntut untuk memiliki etika. Etika bagi mahasiswa dapat menjadi alat kontrol di dalam melakukan suatu tindakan. Etika dapat menjadi gambaran bagi mahasiswa dalam mengambil suatu keputusan atau dalam melakukan sesuatu yang baik atau yang buruk. Etika mahasiswa dapat dipengaruhi oleh kecerdasan emosi dan budaya religius mahasiswa itu sendiri.

Kecerdasan emosional adalah kemampuan mengenali perasaan diri sendiri dan perasaan orang lain, memotivasi diri sendiri, serta mengelola emosi dengan baik pada diri sendiri dan dalam hubungan dengan orang lain, seperti yang dikemukakan Goleman (1996) menyatakan bahwa kemampuan individu untuk mengenali perasaan diri sendiri maupun orang lain, memotivasi diri sendiri, dan kemampuan untuk mengendalikan emosi sangat dipengaruhi oleh kecerdasan emosional individu. Apabila dikaitkan dengan aspek etika, kecerdasan emosional dapat mempengaruhi individu dalam membuat keputusan etis. Seseorang dapat berperilaku atau membuat keputusan etis apabila individu tersebut memiliki kecakapan dasar atau dimensi kecerdasan emosional yang diungkapkan oleh Lubis (2010), yaitu kesadaran diri, kendali diri, motivasi, empati, dan keterampilan sosial. Ketika individu memiliki kesadaran diri dan kendali diri, individu dapat menganalisa dampak dari tindakan yang akan dilakukan. Perilaku tidak etis sering kali menghasilkan dampak yang negatif, terutama untuk individu 
lainnya dan bahkan dapat merugikan dirinya sendiri. Individu yang sadar akan hal tersebut akan sangat berhati-hati untuk mengendalikan perilaku maupun tindakannya agar tidak melanggar prinsip etika, sehingga tidak merugikan dirinya sendiri maupun orang lain. Hal tersebut dapat dikaitkan ke aspek empati, yaitu kepedulian terhadap individu lainnya.

Menyangkut tentang aspek motivasi, Lubis (2010) menyatakan bahwa motivasi dapat membangkitkan semangat untuk mencapai keadaan yang lebih baik serta mampu mengambil inisiatif dan bertindak secara efektif. Apabila dikaitkan dengan aspek etika, individu yang memiliki motivasi yang tinggi memiliki dorongan yang kuat untuk berperilaku sesuai dengan aturan etika. Selain itu, keterampilan sosial akan menguatkan dorongan tersebut, karena pada dasarnya individu yang memiliki keterampilan sosial berusaha untuk menciptakan hubungan yang harmonis antar individu, dalam hal ini adalah hubungan antar individu di lingkungan kampus. Untuk mencapai keharmonisan tersebut, hal yang dapat dilakukan salah satunya adalah dengan bertindak dan berperilaku sesuai dengan etika yang berlaku di lingkungan kampus. Maka dari itu, mahasiswa yang memiliki kecerdasan emosional yang tinggi pada umumnya mampu menunjukkan perilaku etis di lingkungan kampus.

Cooper \& Sawaf dalam Ika (2011) mengatakan bahwa kecerdasan emosional adalah kemampuan merasakan, memahami, dan secara selektif menerapkan daya dan kepekaan emosi sebagai sumber energi dan pengaruh yang manusiawi. Kecerdasan emosi menuntut pemilikan perasaan untuk belajar mengakui, menghargai perasaan pada diri dan orang lain serta menanggapinya dengan tepat, menerapkan secara efektif energy emosi dalam kehidupan sehari-hari. Mahasiswa yang memiliki kecerdasan emosional dapat membedakan perbuatan baik dan buruk, sudah mengetahui apa yang mereka lakukan apakah sudah sesuai dengan keinginan mereka dan apakah tindakan tersebut juga sudah sesuai dengan norma-norma yang ada di masyarakat. Semakin tinggi kecerdasan emosional yang ada pada 
mahasiswa, maka perilaku etis semakin meningkat.

Pembiasaan berperilaku religius perguruan tinggi ternyata mampu mengantarkan mahasiswa untuk berbuat yang sesuai dengan etika. Dampak dari pembiasaan perilaku religius tersebut berpengaruh pada tiga hal yaitu: (1) Pikiran, siswa mulai belajar berpikir positif (positif thinking). Hal ini dapat dilihat dari perilaku mereka untuk selalu mau mengakui kesalahan sendiri dan mau memaafkan orang lain. Mahasiswa juga mulai menghilangkan prasangka buruk terhadap orang lain. Mereka selalu terbuka dan mau bekerjasama dengan siapa saja tanpa memandang perbedaan agama, suku, dan ras. (2) Ucapan, perilaku yang sesuai dengan etika adalah tutur kata siswa yang sopan, misalnya mengucapkan salam kepada dosen, mengucapkan terima kasih jika diberi sesuatu, meminta maaf jika melakukan kesalahan, berkata jujur, dan sebagainya. Hal sekecil ini jika dibiasakan sejak kecil akan menumbuhkan sikap positif. Sikap tersebut misalnya menghargai pendapat orang lain, jujur dalam bertutur kata dan bertingkah laku. (3) Tingkah laku, tingkah laku yang terbentuk dari perilaku religius tentunya tingkah laku yang benar, yang sesuai dengan etika. Tingkah laku tersebut di antaranya empati, hormat, kasih sayang, dan kebersamaan.

Jika mahasiswa sudah terbiasa hidup dalam lingkungan yang penuh dengan kebiasaan religius, kebiasaan-kebiasaan itu pun akan melekat dalam dirinya dan diterapkan di mana pun mereka berada. Begitu juga sikapnya dalam berucap, berpikir dan bertingkah laku akan selalu didasarkan norma agama, moral dan etika yang berlaku. Adanya religiusitas yang berupa keyakinan, praktek agama, pengalaman, pengetahuan agama, dan pengalaman yang baik dari mahasiswa akan dapat meningkatkan perilaku etis mahasiswa itu sendiri. Seseorang yang memiliki tingkat religiusitas yang tinggi di dalam dirinya sebelum bertindak akan terlebih dahulu memikirkan apakan tindakannya sudah sesuai dengan syariat agamanya. Seseorang yang religius akan meyakini bahwa Allah mengetahui setiap tindakan mereka dan segala tindakan baik atau buruk akan mendapat balasan di hari akhir. 


\section{PENUTUP}

\section{Kesimpulan}

Berdasarkan hasil analisis data penulis menyimpulkan sebagai berikut: terdapat pengaruh kecerdasan emosi dan budaya religius terhadap perilaku etis mahasiswa Perguruan Tinggi Kementerian Agama se-Lombok, hal ini dibuktikan bahwa pada taraf signifikansi $\alpha 0,05$ diperoleh $F_{\text {hitung }}\left(F_{h}=287.76\right)$ lebih besar dari $F_{\text {tabel }}\left(F_{t} \alpha 0,05=3.063\right)$ sehingga $\mathrm{H}_{\mathrm{o}}$ ditolak dan $\mathrm{H}_{1}$ diterima.

\section{Saran}

Saran dari penulis agar mahasiswa memiliki perilaku etis: (1) Dosen di Perguruan Tinggi Kementerian Agama untuk mengajarkan dan menerapkan nilai-nilai etis di perguruan tinggi, agar mahasiswa menjadi terbiasa berperilaku etis dalam kesehariannya, (2) Pejabat struktural (Rektor, Wakil Rektor, Dekan, Kajur/Ketua Program Studi) dapat mengetahui faktor-faktor penyebab yang menyebabkan mahasiswa berprilaku etis atau tidak etis sehingga dapat membuat kebijakan agar mahasiswa memiliki perilaku etis.

\section{DAFTAR PUSTAKA}

Aldag, R., Wayne, R. (1997). Employee Value Added, Newyork. Center For Orgazizational Effec tiveness Inc.

Arikunto, S. (1999). Prosedur Penelitian Suatu Pendekatan Praktek. Jakarta: Rineka Cipta.

. (2002). Dasar-dasar evaluasi pendidikan, cetakan ke II. Jakarta: Bumi Aksara.

Ginanjar, A. (2003). Rahasia Sukses Membangkiitkan ESQ Power: Sebuah Inner Journey Melalui Ihsan. Jakarta: ARGA.

Sahlan, A. (2009). Mewujudkan Budaya Religius di Sekolah. Malang: UIN Maliki PRESS 
Goleman, D. (2004). Emotional Intelligence atau kecerdasan emosional, Mengapa EI lebih penting dari pada IQ (T. Hermaya, Penerj.). Jakarta: Gramedia Pustaka Utama.

Djalil, S. \& Partner. (2003). Panduan Good Corporate Governance PT (Perseo) Pelabuhan Indonesia III Surabaya, 2003

Uno, H.B. (2006). Orientasi Baru dalam Psikologi Pembelajaran. Jakarta: Bumi Aksara.

Alder, H. (2001). Boost Your intelligence: Pacu EQ dan IQ (C. Prianingsih, Penerj.). Jakarta: Erlangga.

George, J.M. \& Jones, G.R. (2002). Understanding and Managing Organizational Behavior. New Jersey: Prentice Hall.

Chelagat, L. J., Chepkwony, P.K., \& Kemboi, A. (2015). Effect of Organizational Citizenship Behavior on Employee Performance in Banking Sector, Nairobi County, Kenya. International Journal of Business, Humanities and Technology, 5 (4).

Kotter, J.P., \& Heskett, J.L., (1992). Dampak Budaya Perusahaan Terhadap Kinerja (B. Molan, Penerj.). Jakarta: Prehallindo.

Muallip. (2014). Manajemen Pembelajaran Pendidikan Agama Islam dalam Mewujudkan Budaya Religiuss. Pascasarjana UIN Maulana Malik Ibrahim Malang.

Muhaimin. (2001). Paradigma Pendidikan Islam. Bandung: Rosdakarya.

Organ, D.W. (2006). Organizational Citizenship Behavior: The Good Soldier Syndrome Lexington: Lexington Books.

Robbins, S.P., \& Coulter, M. (2012). Management, 11 $11^{\text {th }}$ edition. New Jersey: Pearson Education Inc.

Stein S.J., \& Howard, E. (2003). Ledakan EQ:15 Prinsip Dasar kecerdasn Emosional Meraih Sukses (T.R. Januarsari \& Y. Murtanto, Penerj.). Bandung: Kaifa.

Sugiyono. (2006). Statistika Untuk Penelitian. Bandung: ALFABETA. Suryabrata, S. (1985). Metodologi Penelitian. Jakarta. Rajawali. 
Maujud, F., Isrososiawan, S., \& Nurman, M. (2019). PENGARUH KECERDASAN EMOSI DAN BUDAYA RELIGIUS TERHADAP PERILAKU ETIS MAHASISWA PERGURUAN TINGGI KEMENTERIAN AGAMA SE-LOMBOK. Jurnal Tatsqif, 17(2), 149-170. https://doi.org/10.20414/jtq.v17i2.1359

Hadi, S. (1994). Statistik II. Jakarta. Andi Offset.

Baldwin, T.T., Bommer, W.H., \& Rubin, R.S. 2012. Managing Organizational Behavior, second edition. New York: McGraw-Hill International edition.

Departemen Pendidikan dan Kebudayaan. (1998). Kamus Besar Bahasa Indonesia. Jakarta: Balai Pustaka. 